\title{
Using County Typology Informed by Population Size to Understand Key Audience Characteristics for Tailored Landscape Water Conservation Programs ${ }^{1}$
}

\author{
Laura A. Sanagorski Warner and John M. Diaz ${ }^{2}$
}

\section{Abstract}

A major priority for UF/IFAS is the promotion of sciencebased landscape management practices to conserve water resources. This publication outlines specific opportunities that exist for tailoring landscape water conservation programs to Floridians who live in more and less metropolitan areas. People who live in more populated counties in Florida tend to have longer residency tenure, are more likely to live within a community governed by a homeowners' association, and more likely to hire a landscape professional. The more metropolitan audience demonstrates increased engagement with specific water conservation practices as compared to other conservation strategies. Understanding these differences among audience subgroups can provide insights to guide impactful Extension programs.

\section{Introduction}

Florida's growing number of residents and their home landscapes (consisting of irrigated and fertilized plants, turfgrass, and trees) can influence water resources either positively or negatively, depending on how landscapes are managed. Urbanization and population growth in Florida present both challenges and opportunities for landscape water conservation Extension programming. A major
UF/IFAS Extension focus is enhancing and protecting water quality, quantity, and supply (UF/IFAS, 2013).

Successful Extension programs depend on behavior change (Monaghan \& Monroe, 2013); yet, encouraging people to change is a complex process. Extension can use a strategy known as audience segmentation to encourage water conservation (Monaghan, Warner, Telg, \& Irani, 2014). Audience segmentation is a concept Extension can use to divide a major group (such as Florida residents) into smaller groups with members who are similar to one another in ways that make sense for Extension programming (Rogers, 2003). Here, we apply this concept using population size (or how metropolitan) an Extension client's county is.

It is important that Extension finds ways to extend its impact to serve everyone (Harder \& Wells, 2017).

Therefore, the information presented in this document was collected to identify ways to best position water conservation programs for Florida's larger metropolitan areas as well as the state's less populated counties.

1. This document is AEC651, one of a series of the Agricultural Education and Communication Department, UF/IFAS Extension. Original publication date August 2018. Visit the EDIS website at http://edis.ifas.ufl.edu.

2. Laura A. Sanagorski Warner, assistant professor; and John M. Diaz, assistant professor, Department of Agricultural Education and Communication; UF/ IFAS Extension, Gainesville, FL 32611. 


\section{Identifying Florida Residents' Characteristics as a Function of Population Size}

Over the course of three years (2014-2016), we asked approximately 3,500 Floridians about their landscape and water use practices. These individuals were required to have control over their landscape irrigation, meaning they had the opportunity to engage in more conservation practices. We asked this group where their water came from (e.g., city, irrigation well, reclaimed water) and whether they hired professionals for different landscape tasks (e.g., irrigation services, lawn maintenance, tree pruning, pest management, landscape design and installation). We asked them whether they engaged in any landscape water conservation practices from a list of 16 strategies promoted by UF/IFAS (e.g., I calibrate my sprinklers; I have converted turfgrass areas to landscaped beds; I have replaced high water plants with drought tolerant plants; I use a rain sensor to turn off irrigation when it is not needed). Lastly, we asked Floridians about their demographics, including their zip codes. We used the zip codes to determine which county population size segment each individual belonged to:

- metro areas with a population of 1 million or more (e.g., Miami-Dade County, Palm Beach County);

- metro areas with a population of 250,000 to 1 million (e.g., Alachua County, Volusia County);

- metro areas with a population of less than 250,000 (e.g., Bay County, Gulf County); and

- nonmetro areas with a population size of 20,000 or more (e.g., Hendry County, Monroe County; Economic Research Service, 2013).

We found some interesting similarities and differences.

\section{Personal Characteristics}

As population size increases, Floridians tend to be younger and to have lived in Florida longer. For example, in counties with metro areas of 1 million or more residents, the average respondent is 46 years old and has lived in Florida for about 24 years. Those living in less populated locations tend to be older and have lived in the state for a shorter period of time. In counties characterized by nonmetro areas with populations of 20,000 or more, the average respondent was 53 years old and had lived in Florida for less than 20 years. The more populated someone's county is, the more likely they are to live within a homeowners' association (HOA; about $54 \%$ in metro areas of 1 million or more and about $36 \%$ in metro areas with 250,000 or less).

\section{Water Source}

Floridians in all locations use city water over the other possible sources (about half or more in all segments). However, as population size of the studied areas decreased, the use of irrigation wells became more common and the use of reclaimed water became slightly less common. About $40 \%$ of our respondents indicated they used a well in the metro areas with fewer than 250,000 residents and the nonmetro areas with more than 20,000 residents.

\section{Hiring a Landscape Professional}

Residents in the bigger metro areas indicated that they are more likely to hire a landscape professional for all of the services we asked about. The biggest practical differences were for lawn maintenance and tree pruning. As a county's population size decreases, residents indicated that they are less likely to hire a landscape professional for anything; these are do-it-yourselfers.

\section{Landscape Water Conservation Practices}

There are small but important differences in landscape water conservation practices depending on residents' county population size. Residents in larger metropolitan areas are more likely to say they conserve water by using recycled wastewater for irrigation. More residents in the larger metro areas use smart irrigation controls (such as soil moisture sensors) to save water than residents in the less populated counties. Residents in counties with smaller populations were more likely to have replaced high volume irrigation with low volume irrigation, to have converted turfgrass to landscaped beds, to have low-water plants, and to use a rain gauge to monitor rainfall.

\section{How to Use This Information}

Now that similarities and differences have been identified among Floridians living in larger metropolitan and less populated areas, these unique characteristics can be integrated into planned Extension programs. Extension professionals are encouraged to consider the many influences that may lead to these differences, which extend beyond population size alone to include infrastructure, service availability, and other factors. Since people living in more or less densely populated areas save water in different ways, Extension professionals should tailor programs based on the needs of their audience. Table 1 presents the classification of Florida counties by population size. We offer the following recommendations for applying these findings to Extension programs: 
- Encourage strategies that are least used by residents in a particular target audience when they are appropriate methods of conservation. In more populated areas, this includes converting turfgrass to landscaped beds, using a rain gauge to monitor rainfall, and retrofitting the landscape so portions are not irrigation. In less populated areas, this includes using recycled wastewater when infrastructure is available. Promoting under-used conservation strategies is a way to take advantage of the opportunity for more people to adopt a specific conservation strategy.

- Consider emphasizing the compatibility of new landscape water conservation strategies with those that an audience is already using. Residents in more metropolitan areas might be attracted to programs that help them refine strategies they already use (such as smart irrigation controls) and then add in additional compatible strategies, such as low-volume irrigation or reductions in irrigated areas.

- Noticing that metropolitan residents were less engaged with practices considered to be permanent landscape modifications (i.e., installing low-volume irrigation in place of high-volume irrigation or removing turfgrass or high water plants and installing drought-tolerant plants instead); Extension programs serving these audiences should recognize that social norms may be an important factor to these residents. In other words, they want their landscapes to look like their neighbors' and may not want to deviate from a community aesthetic. There may also be HOA restrictions or perceptions of restrictions that prevent these types of landscape modifications. Extension should consider helping these residents to save water while maintaining a uniform look, and also consider promoting conservation strategies on a community scale in these cases.

- Consider who is managing the client's landscape. In more metropolitan areas, it is more likely to be someone other than the resident (and possibly several landscape professionals). In these cases, Extension should consider educating the resident on how to screen potential landscape service providers so they hire someone who will help them save water. Residents can also be trained to specify services and technologies that will lead to water savings from existing professionals and those they hire in the future.

- In more populated areas, Extension programs also need to target landscape professionals because they are performing a number of residential landscape tasks for residents. This represents an opportunity to promote behavior change among a different audience that influences water use in more metropolitan areas. In metropolitan areas with fewer people and nonmetropolitan areas, Extension programming might focus mostly on the residents themselves because they are more likely to be do-it-yourselfers.

- Extension programs should integrate residents' source of water. Municipal water is more common in more metropolitan areas, while wells are more common in less populated counties. Those residents who use well water likely have unique concerns regarding maintenance of their wells and preserving their water supply, and these concerns can be used to target programs towards this audience.

- Consider engaging multiple partners for Extension programming, especially in more metropolitan areas. Residents living in more populated counties may have several landscape service providers and live in HOAs, implying there are many decision-makers influencing a single residental landscape.

- There may be a link between living in a more populated area and engaging in different, and possibly fewer, landscape water conservation practices. This implies that less contact with nature may translate to less conservation, or different approaches to conservation. Extension should think about ways to connect people who are not exposed to natural resources, such as local water bodies, with their environment as a means to motivate them to protect it. Consider field trips or educational displays to help Extension clients learn about Florida's water bodies and important concepts such as runoff and watersheds.

\section{Conclusions}

Floridians save water in different ways depending on whether they live in a more or less populated area, and these conservation factors are influenced by a number of factors. Future research should examine these factors more closely and consider analyzing conservation behaviors at a more local level. Extension professionals should help Floridians conserve by integrating the unique characteristics of more and less densely populated areas into Extension programs. Evidence shows that by understanding these characteristics, tailored programs can be developed to increase the likehood of achieving behavior change. For more information about this specific study, please see Warner, Diaz, and Kumar Chaudhary (2018).

\section{Acknowledgements}

The authors thank the Center for Landscape Conservation and Ecology (http://clce.ifas.ufl.edu) for supporting the research presented in this publication. 


\section{References}

Economic Research Service. (2013). Rural-urban continuum codes. Washington, DC: United States Department of Agriculture. Retrieved from https://www.ers.usda.gov/ data-products/rural-urban-continuum-codes/

Harder, A., \& Wells, O. (2017). Tampa Bay Extension agents' views of urban extension: Philosophy and program strategies. Journal of Human Sciences and Extension, 5(2), 55-69. Retrieved from https://docs.wixstatic.com/ugd/c8fe 6e_74f3a32b703e4a4fb0e98d2b95861a4f.pdf

Monaghan, P., \& Monroe, M. (2013). Improving behavioral outcomes in extension using the tools of community-based social marketing (CBSM). AEC486. Gainesville: University of Florida Institute of Food and Agricultural Sciences.

Retrieved from http://edis.ifas.ufl.edu/wc149

Monaghan, P., Warner, L., Telg, R., \& Irani, T. (2014).

Improving extension program development using audience segmentation. AEC538. Gainesville: University of Florida Institute of Food and Agricultural Sciences. Retrieved from http://edis.ifas.ufl.edu/wc188

Rogers, E. M. (2003). Diffusion of innovations (3rd ed.). New York, NY: Free Press.

University of Florida Institute of Food and Agricultural Sciences [UF/IFAS]. (2013). Shaping solutions for Florida's future: The University of Florida extension roadmap 20132023. University of Florida. Retrieved from http://pdec.ifas. ufl.edu/roadmap/FloridaExtensionRoadmap_2013-2023. pdf

Warner, L. A, Diaz, J. M., \& Kumar Chaudhary, A. (2018). Informing urban landscape water conservation extension programs using behavioral research. Journal of Agricultural Education, 59(2), 32-48. doi:10.5032/jae.2018.02032 
Table 1. Florida county rural-urban continuum classification. Adapted from Economic Research Service (2013).

\begin{tabular}{|c|c|c|}
\hline County & Population in 2010 census & Description \\
\hline Alachua County & 247,336 & $\begin{array}{l}\text { Metro - Counties in metro areas of } 250,000 \text { to } 1 \text { million } \\
\text { population }\end{array}$ \\
\hline Baker County & 27,115 & $\begin{array}{l}\text { Metro - Counties in metro areas of } 1 \text { million population or } \\
\text { more }\end{array}$ \\
\hline Bay County & 168,852 & $\begin{array}{l}\text { Metro - Counties in metro areas of } 250,000 \text { to } 1 \text { million } \\
\text { population }\end{array}$ \\
\hline Bradford County & 28,520 & $\begin{array}{l}\text { Nonmetro - Urban population of } 2,500 \text { to } 19,999 \text {, adjacent } \\
\text { to a metro area }\end{array}$ \\
\hline Brevard County & 543,376 & $\begin{array}{l}\text { Metro - Counties in metro areas of } 250,000 \text { to } 1 \text { million } \\
\text { population }\end{array}$ \\
\hline Broward County & $1,748,066$ & $\begin{array}{l}\text { Metro - Counties in metro areas of } 1 \text { million population or } \\
\text { more }\end{array}$ \\
\hline Calhoun County & 14,625 & $\begin{array}{l}\text { Nonmetro - Urban population of } 2,500 \text { to } 19,999 \text {, adjacent } \\
\text { to a metro area }\end{array}$ \\
\hline Charlotte County & 159,978 & $\begin{array}{l}\text { Metro - Counties in metro areas of fewer than } 250,000 \\
\text { population }\end{array}$ \\
\hline Citrus County & 141,236 & $\begin{array}{l}\text { Metro - Counties in metro areas of fewer than } 250,000 \\
\text { population }\end{array}$ \\
\hline Clay County & 190,865 & $\begin{array}{l}\text { Metro - Counties in metro areas of } 1 \text { million population or } \\
\text { more }\end{array}$ \\
\hline Collier County & 321,520 & $\begin{array}{l}\text { Metro - Counties in metro areas of } 250,000 \text { to } 1 \text { million } \\
\text { population }\end{array}$ \\
\hline Columbia County & 67,531 & $\begin{array}{l}\text { Nonmetro - Urban population of } 20,000 \text { or more, adjacent } \\
\text { to a metro area }\end{array}$ \\
\hline DeSoto County & 34,862 & $\begin{array}{l}\text { Nonmetro - Urban population of } 2,500 \text { to } 19,999 \text {, adjacent } \\
\text { to a metro area }\end{array}$ \\
\hline Dixie County & 16,422 & $\begin{array}{l}\text { Nonmetro - Urban population of } 2,500 \text { to } 19,999 \text {, adjacent } \\
\text { to a metro area }\end{array}$ \\
\hline Duval County & 864,263 & $\begin{array}{l}\text { Metro - Counties in metro areas of } 1 \text { million population or } \\
\text { more }\end{array}$ \\
\hline Escambia County & 297,619 & $\begin{array}{l}\text { Metro - Counties in metro areas of } 250,000 \text { to } 1 \text { million } \\
\text { population }\end{array}$ \\
\hline Flagler County & 95,696 & $\begin{array}{l}\text { Metro - Counties in metro areas of } 250,000 \text { to } 1 \text { million } \\
\text { population }\end{array}$ \\
\hline Franklin County & 11,549 & $\begin{array}{l}\text { Nonmetro - Urban population of } 2,500 \text { to } 19,999 \text {, adjacent } \\
\text { to a metro area }\end{array}$ \\
\hline Gadsden County & 46,389 & $\begin{array}{l}\text { Metro - Counties in metro areas of } 250,000 \text { to } 1 \text { million } \\
\text { population }\end{array}$ \\
\hline Gilchrist County & 16,939 & $\begin{array}{l}\text { Metro - Counties in metro areas of } 250,000 \text { to } 1 \text { million } \\
\text { population }\end{array}$ \\
\hline Glades County & 12,884 & $\begin{array}{l}\text { Nonmetro - Urban population of } 2,500 \text { to } 19,999 \text {, adjacent } \\
\text { to a metro area }\end{array}$ \\
\hline Gulf County & 15,863 & $\begin{array}{l}\text { Metro - Counties in metro areas of fewer than } 250,000 \\
\text { population }\end{array}$ \\
\hline Hamilton County & 14,799 & $\begin{array}{l}\text { Nonmetro - Urban population of } 2,500 \text { to } 19,999 \text {, adjacent } \\
\text { to a metro area }\end{array}$ \\
\hline Hardee County & 27,731 & $\begin{array}{l}\text { Nonmetro - Urban population of } 2,500 \text { to } 19,999 \text {, adjacent } \\
\text { to a metro area }\end{array}$ \\
\hline Hendry County & 39,140 & $\begin{array}{l}\text { Nonmetro - Urban population of } 20,000 \text { or more, adjacent } \\
\text { to a metro area }\end{array}$ \\
\hline Hernando County & 172,778 & $\begin{array}{l}\text { Metro - Counties in metro areas of } 1 \text { million population or } \\
\text { more }\end{array}$ \\
\hline
\end{tabular}




\begin{tabular}{|c|c|c|}
\hline County & Population in 2010 census & Description \\
\hline Highlands County & 98,786 & $\begin{array}{l}\text { Metro - Counties in metro areas of fewer than 250,000 } \\
\text { population }\end{array}$ \\
\hline Hillsborough County & $1,229,226$ & $\begin{array}{l}\text { Metro - Counties in metro areas of } 1 \text { million population or } \\
\text { more }\end{array}$ \\
\hline Holmes County & 19,927 & $\begin{array}{l}\text { Nonmetro - Urban population of } 2,500 \text { to } 19,999 \text {, adjacent } \\
\text { to a metro area }\end{array}$ \\
\hline Indian River County & 138,028 & $\begin{array}{l}\text { Metro - Counties in metro areas of fewer than } 250,000 \\
\text { population }\end{array}$ \\
\hline Jackson County & 49,746 & $\begin{array}{l}\text { Nonmetro - Urban population of } 2,500 \text { to } 19,999 \text {, adjacent } \\
\text { to a metro area }\end{array}$ \\
\hline Jefferson County & 14,761 & $\begin{array}{l}\text { Metro - Counties in metro areas of } 250,000 \text { to } 1 \text { million } \\
\text { population }\end{array}$ \\
\hline Lafayette County & 8,870 & $\begin{array}{l}\text { Nonmetro - Completely rural or less than 2,500 urban } \\
\text { population, not adjacent to a metro area }\end{array}$ \\
\hline Lake County & 297,052 & $\begin{array}{l}\text { Metro - Counties in metro areas of } 1 \text { million population or } \\
\text { more }\end{array}$ \\
\hline Lee County & 618,754 & $\begin{array}{l}\text { Metro - Counties in metro areas of } 250,000 \text { to } 1 \text { million } \\
\text { population }\end{array}$ \\
\hline Leon County & 275,487 & $\begin{array}{l}\text { Metro - Counties in metro areas of } 250,000 \text { to } 1 \text { million } \\
\text { population }\end{array}$ \\
\hline Levy County & 40,801 & $\begin{array}{l}\text { Nonmetro - Urban population of } 2,500 \text { to } 19,999 \text {, adjacent } \\
\text { to a metro area }\end{array}$ \\
\hline Liberty County & 8,365 & $\begin{array}{l}\text { Nonmetro - Completely rural or less than 2,500 urban } \\
\text { population, adjacent to a metro area }\end{array}$ \\
\hline Madison County & 19,224 & $\begin{array}{l}\text { Nonmetro - Urban population of } 2,500 \text { to } 19,999 \text {, adjacent } \\
\text { to a metro area }\end{array}$ \\
\hline Manatee County & 322,833 & $\begin{array}{l}\text { Metro - Counties in metro areas of } 250,000 \text { to } 1 \text { million } \\
\text { population }\end{array}$ \\
\hline Marion County & 331,298 & $\begin{array}{l}\text { Metro - Counties in metro areas of } 250,000 \text { to } 1 \text { million } \\
\text { population }\end{array}$ \\
\hline Martin County & 146,318 & $\begin{array}{l}\text { Metro - Counties in metro areas of } 250,000 \text { to } 1 \text { million } \\
\text { population }\end{array}$ \\
\hline Miami-Dade County & $2,496,435$ & $\begin{array}{l}\text { Metro - Counties in metro areas of } 1 \text { million population or } \\
\text { more }\end{array}$ \\
\hline Monroe County & 73,090 & $\begin{array}{l}\text { Nonmetro - Urban population of } 20,000 \text { or more, adjacent } \\
\text { to a metro area }\end{array}$ \\
\hline Nassau County & 73,314 & $\begin{array}{l}\text { Metro - Counties in metro areas of } 1 \text { million population or } \\
\text { more }\end{array}$ \\
\hline Okaloosa County & 180,822 & $\begin{array}{l}\text { Metro - Counties in metro areas of fewer than } 250,000 \\
\text { population }\end{array}$ \\
\hline Okeechobee County & 39,996 & $\begin{array}{l}\text { Nonmetro - Urban population of } 20,000 \text { or more, adjacent } \\
\text { to a metro area }\end{array}$ \\
\hline Orange County & $1,145,956$ & $\begin{array}{l}\text { Metro - Counties in metro areas of } 1 \text { million population or } \\
\text { more }\end{array}$ \\
\hline Osceola County & 268,685 & $\begin{array}{l}\text { Metro - Counties in metro areas of } 1 \text { million population or } \\
\text { more }\end{array}$ \\
\hline Palm Beach County & $1,320,134$ & $\begin{array}{l}\text { Metro - Counties in metro areas of } 1 \text { million population or } \\
\text { more }\end{array}$ \\
\hline Pasco County & 464,697 & $\begin{array}{l}\text { Metro - Counties in metro areas of } 1 \text { million population or } \\
\text { more }\end{array}$ \\
\hline Pinellas County & 916,542 & $\begin{array}{l}\text { Metro - Counties in metro areas of } 1 \text { million population or } \\
\text { more }\end{array}$ \\
\hline
\end{tabular}




\begin{tabular}{|c|c|c|}
\hline County & Population in 2010 census & Description \\
\hline Polk County & 602,095 & $\begin{array}{l}\text { Metro - Counties in metro areas of } 250,000 \text { to } 1 \text { million } \\
\text { population }\end{array}$ \\
\hline Putnam County & 74,364 & $\begin{array}{l}\text { Nonmetro - Urban population of } 20,000 \text { or more, adjacent } \\
\text { to a metro area }\end{array}$ \\
\hline St. Johns County & 190,039 & $\begin{array}{l}\text { Metro-Counties in metro areas of } 1 \text { million population or } \\
\text { more }\end{array}$ \\
\hline St. Lucie County & 277,789 & $\begin{array}{l}\text { Metro - Counties in metro areas of } 250,000 \text { to } 1 \text { million } \\
\text { population }\end{array}$ \\
\hline Santa Rosa County & 151,372 & $\begin{array}{l}\text { Metro - Counties in metro areas of } 250,000 \text { to } 1 \text { million } \\
\text { population }\end{array}$ \\
\hline Sarasota County & 379,448 & $\begin{array}{l}\text { Metro - Counties in metro areas of } 250,000 \text { to } 1 \text { million } \\
\text { population }\end{array}$ \\
\hline Seminole County & 422,718 & $\begin{array}{l}\text { Metro-Counties in metro areas of } 1 \text { million population or } \\
\text { more }\end{array}$ \\
\hline Sumter County & 93,420 & $\begin{array}{l}\text { Metro - Counties in metro areas of fewer than } 250,000 \\
\text { population }\end{array}$ \\
\hline Suwannee County & 41,551 & $\begin{array}{l}\text { Nonmetro - Urban population of } 2,500 \text { to } 19,999 \text {, adjacent } \\
\text { to a metro area }\end{array}$ \\
\hline Taylor County & 22,570 & $\begin{array}{l}\text { Nonmetro - Urban population of } 2,500 \text { to } 19,999 \text {, adjacent } \\
\text { to a metro area }\end{array}$ \\
\hline Union County & 15,535 & $\begin{array}{l}\text { Nonmetro - Urban population of } 2,500 \text { to } 19,999 \text {, adjacent } \\
\text { to a metro area }\end{array}$ \\
\hline Volusia County & 494,593 & $\begin{array}{l}\text { Metro - Counties in metro areas of } 250,000 \text { to } 1 \text { million } \\
\text { population }\end{array}$ \\
\hline Wakulla County & 30,776 & $\begin{array}{l}\text { Metro - Counties in metro areas of } 250,000 \text { to } 1 \text { million } \\
\text { population }\end{array}$ \\
\hline Walton County & 55,043 & $\begin{array}{l}\text { Metro - Counties in metro areas of fewer than } 250,000 \\
\text { population }\end{array}$ \\
\hline Washington County & 24,896 & $\begin{array}{l}\text { Nonmetro - Urban population of } 2,500 \text { to } 19,999 \text {, adjacent } \\
\text { to a metro area }\end{array}$ \\
\hline
\end{tabular}

